\title{
Strategies to Enhance the Productivity of Rainfed Off- Season Maize
}

\section{Bruna Gomes Magalhães ${ }^{1}$, Camilo de Lelis Teixeira de Andrade ${ }^{2}$, Priscila Ponciana Gomes da Silva ${ }^{3}$, Miguel Marques Gontijo-Neto ${ }^{4}$, Daniela de Carvalho Lopes ${ }^{5}$, Bruno Ferreira de Melo $^{6}$, Axel Garcia y Garcia ${ }^{7}$}

\author{
${ }^{1}$ MSc Student, Fed. Univ. of Sao Joao del Rei, bruna@setelagoas.com.br \\ ${ }^{2}$ Researcher, Embrapa Maize and Sorghum, camilo.andrade@embrapa.br \\ ${ }^{3}$ Undergrad Fellow, Fed. Univ. of Sao Joao del Rei, prigomes18@hotmail.com \\ ${ }^{4}$ Researcher, Embrapa Maize and Sorghum, miguel.gontijo@embrapa.br \\ ${ }^{5}$ Assistant Professor, Fed. Univ. of Sao Joao del Rei, danielalopes@ufsj.edu.br \\ ${ }^{6}$ Undergrad Fellow, UNIFEMM, brunoferreiramelo@hotmail.com \\ Genetics, Lamberton, MN, axel@umn.edu \\ Written for presentation at the \\ 2016 ASABE Annual International Meeting \\ Sponsored by ASABE \\ Orlando, Florida \\ July 17-20, 2016
}

${ }^{7}$ Assistant Professor, University of Minnesota Cropping Systems, Department of Agronomy and Plant

\begin{abstract}
In Brazil, off-season rainfed maize is usually affected by limited water due to irregularities in rainfall. Alternatives to mitigate these effects include ground cover to reduce evaporation losses and the use of cultivars with a deeper rooting system. We conducted a study in Goias, Brazil, to evaluate the influence of different crop management strategies to mitigate the effect of limited water in maize yield. Modeling was used to simulate scenarios that consisted of $0,3.5$ and $5.0 \mathrm{t} \mathrm{ha}^{-1}$ of soybean residue left on the soil surface combined with cultivar ideotypes with $0.30 \mathrm{~m}, 0.50 \mathrm{~m} 0.70 \mathrm{~m}$ deep rooting system grown with 60 and $340 \mathrm{~kg}$ $\mathrm{ha}^{-1}$ of nitrogen. The results showed that maintaining residue in the soil surface in combination with the use of cultivars with deeper rooting systems favored higher yields of off-season maize. Our results also indicated that a cultivar with rooting system in the top $0.50 \mathrm{~m}$ of the soil fertilized with a high nitrogen rate tended to be more efficient in the use of the soil available water.
\end{abstract}

Keywords. Zea mays L.; no-tillage; rooting system; off-season maize; modeling

The authors are solely responsible for the content of this meeting presentation. The presentation does not necessarily reflect the official position of the American Society of Agricultural and Biological Engineers (ASABE), and its printing and distribution does not constitute an endorsement of views which may be expressed. Meeting presentations are not subject to the formal peer review process by ASABE editorial committees; therefore, they are not to be presented as refereed publications. Citation of this work should state that it is from an ASABE meeting paper. EXAMPLE: Author's Last Name, Initials. 2016. Title of Presentation. ASABE Paper No. ---. St. Joseph, Mich.: ASABE. For information about securing permission to reprint or reproduce a meeting presentation, please contact ASABE at rutter@asabe.org or 269-932-7004 (2950 Niles Road, St. Joseph, MI 49085-9659 USA). 


\section{Introduction}

Most of the maize produced in Brazil comes from its off-season production system, which has a great impact in the agribusiness sector of the country (Foloni et al., 2014). The system is mostly practiced in the Southeast and Central-West regions of Brazil. In the latter, the State of Goias is of interest as the off-season maize in rotation with soybean has become the most important practice. The system is rainfed, therefore subject to weather uncertainties especially affecting the availability of water in the soil profile and ultimately, yield. As a consequence, the regional average maize yield of $4800 \mathrm{~kg} \mathrm{ha}^{-1}$ (IBGE, 2015) is below its potential (Leite et al., 2013). Efforts to reduce such gap are of high importance for the sector. In the State of Goias the average rainfall amount from January to April is $782 \mathrm{~mm}$ (Cardoso et al., 2014), higher than the minimum of 300 to 350 $\mathrm{mm}$ of rainfall required by the crop, provided that it is well distributed throughout the growing season (Dourado Neto et al., 2004).

An option to mitigate the effects of limited water in crop production is no-till, a practice that do not disturbs the soil and maintains the residue of the previous crop on surface. In addition to its beneficial effects on erosion control and easiness of sowing, no-till also helps to prevent the loss of soil moisture. Crops residue favor the increase of organic matter, helps in maintaining the soil temperature and, especially, water in the soil profile (Moreira et al., 2011). Indirectly, it can also attenuate the impact of the intra-seasonal weather variation on yield. Crops residue kept on the soil surface and no-tillage may also improve the soil-water infiltration (Floss, 2002). Another alternative to minimize the effect of limited water in crop production is the use of crops with deep rooting system to explore a larger volume of soil in search for water and nutrients (Alvarenga \& Cruz, 2003). In tropical conditions, however, this may be limited due to the presence of toxic aluminum $\left(\mathrm{Al}^{3+}\right)$ and low $\mathrm{pH}$, conditions that may compromise the root development of maize and ultimately the ability of the plant to uptake water and nutrients. While this is solved with either the use of cultivars tolerant to $\mathrm{Al}^{3+}$ or with the use of lime and gypsum amendments (Zandoná et al., 2015), the rooting system of maize under Brazilian soil conditions is reported to range from 0.4 to $0.5 \mathrm{~m}$ (Resende \& Albuquerque, 2002).

Few studies have been conducted to evaluate the interaction crop $\mathrm{x}$ weather conditions (Zandoná et al., 2015). Accordingly, crop models may be used to advance our understanding on the effect of weather and climate on growth and yield of crops. This study combined field research results and the Cropping System Model (CSM)CERES-Maize (Jones et al., 1986) of the Decision Support System for Agrotechnology Transfer, DSSAT (Jones et al., 2003). DSSAT consists of a set of process-based models for various crops, which provides routines for assessing the interaction of plant with soil, climate and crop management practices. The models of DSSAT have been successfully used worldwide to evaluate the effectiveness of management strategies to mitigate the effects of climate change on maize (Amaral et al, 2014; Silva et al, 2014; Souza et al, 2014; Babel \& Turyatunga, 2015; Kassie et al, 2015).

The goal of this study was to evaluate the effectiveness of management practice to mitigate the effects of limited water in maize grown off-season in Central-West Brazil. The specific objectives were to a) evaluate the individual and combined effect of residue $\mathrm{x}$ root depth $\mathrm{x} \mathrm{N}$ rates on yield and b) determine the best management practices to improve the yield of off-season maize.

\section{Material and methods}

The approach

This study was conducted using field research results and modeling. For the former, results from eight experimental trials conducted in Sete Lagoas, Papagaios, and Patos de Minas, state of Minas Gerais, Brazil, obtained under optimum conditions of growth, were used to parameterize the model. Results from seve field trials conducted in the same counties of Minas Gerais and in Paracatu, Minas Gerais and Rio Verde, state of Goias, Brazil, were used for evaluation. For the latter, the CSM-CERES-MAIZE model (JONES et al., 1986) of DSSAT (Jones et al., 2003; HOOGENBOOM et al., 2014), was used to simulate maize production under conditions in Rio Verde, State of Goias, located in the Central-West region of Brazil, characterized as one of the most important off-season maize production areas in the country.

The climate of the region is characterized as Aw, (Koppen-Geiger, 1936), featuring this region as Tropical with a dry winter (Cardoso et al., 2014). The monthly average maximum temperature can be as high as $32.5^{\circ} \mathrm{C}$ in October and the monthly average minimum temperature can be as low as $13.1^{\circ} \mathrm{C}$ in July (Figure $1 \mathrm{~A}$ ). Rainfall occurs in all months of the year; March is the wettest with an average of $261 \mathrm{~mm}$ and July the driest with an average of $16 \mathrm{~mm}$. The average annual rainfall is $1630 \mathrm{~mm}$ (Figure 1B). Average solar radiation ranges from 14.1 to $20.3 \mathrm{MJ} \mathrm{m}^{-2} \mathrm{day}^{-1}$ in June and November, respectively (Figure 1C). While the conditions to grow offseason maize seem to fulfill the requirements of the crop, the inter-annual and intra-seasonal weather 
variability in the region is an actual risk to crop failure due to limited water supply.
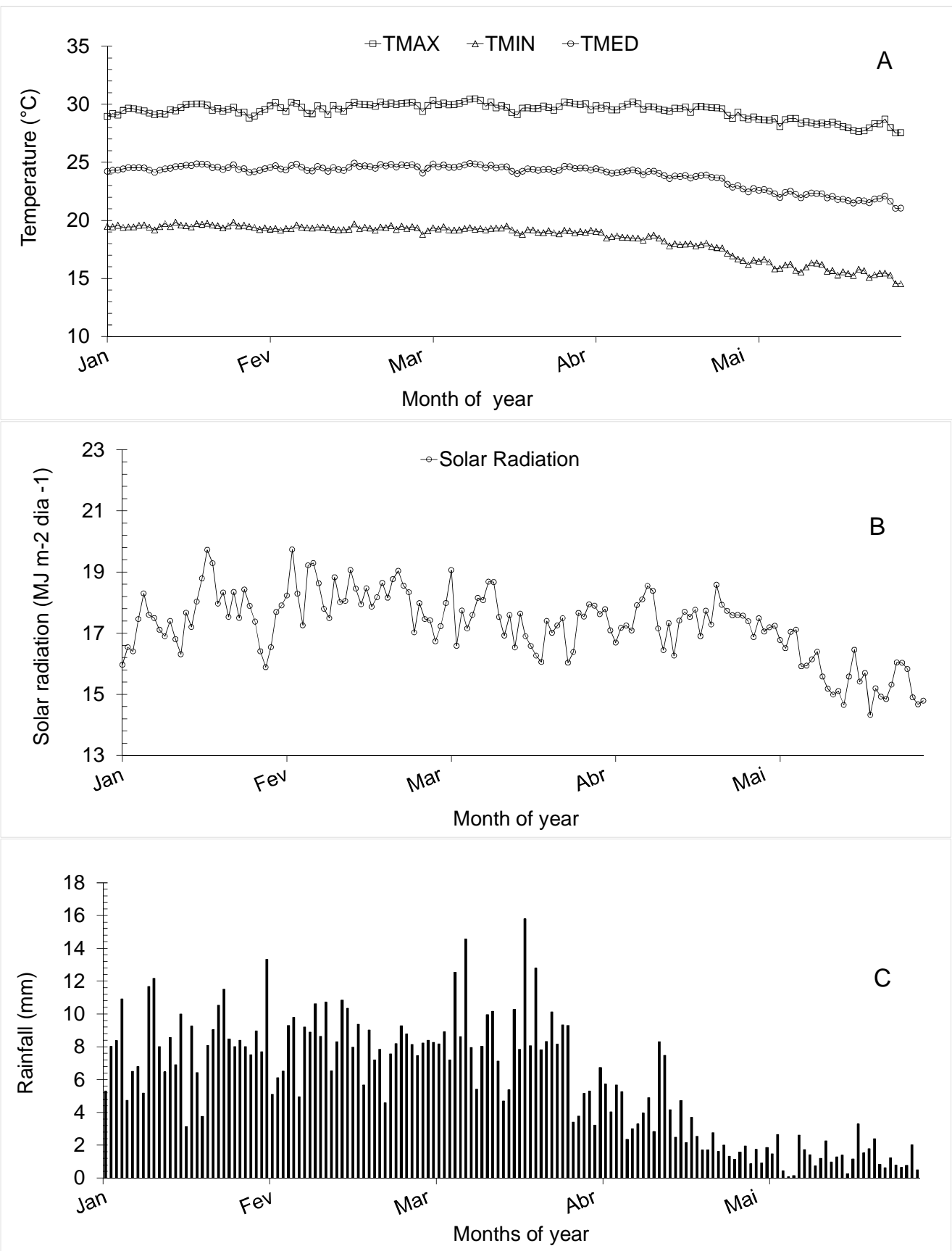

Figure 1. Long-term (33 years) average daily maximum, minimum and air temperature (A), solar radiation (B) and rainfall (C) in Rio Verde, Goias, Brazil.

The soil fertility and the water holding capacity of a representative soil profile of Rio Verde were used as input to the model (Table 1). The soil density ranged from 950 to $1004 \mathrm{~kg} \mathrm{~m}^{-3}$, with the largest value observed in the 0-0.10 m layer. The soil available water was around $8 \mathrm{~mm}$ in all layers. The soil-water availability to a depth of $0.4 \mathrm{~m}$, which encompasses most of the maize rooting system (Rhoads \& Bennett, 1990), was $32 \mathrm{~mm}$. The cumulative sum of bases in the $0-0.40 \mathrm{~m}$ layer was $4.23 \mathrm{cmolc} \mathrm{dm}^{-3}$, a reference of suitable soil fertility. The pH in water in all soil profile layers varied from 5.1 to 5.7 , representing an average acidity condition in the region (Ribeiro et al., 1999). 
Table 1. Soil profile characteristics of the experimental area of the University of Rio Verde, Brazil.

\begin{tabular}{|c|c|c|c|c|c|}
\hline $\begin{array}{l}\text { Layer base } \\
\text { depth }(m)\end{array}$ & $\begin{array}{l}\text { Lower limit } \\
\qquad\left(\mathrm{m}^{3} \mathrm{~m}^{-3}\right)\end{array}$ & $\begin{array}{l}\text { Upper limit } \\
\left(\mathrm{m}^{3} \mathrm{~m}^{-3}\right)\end{array}$ & $\begin{array}{l}\text { Saturation } \\
\qquad\left(\mathrm{m}^{3} \mathrm{~m}^{-3}\right)\end{array}$ & $\mathrm{pH}$ in water & $\begin{array}{l}\text { Bulk density } \\
\qquad\left(\mathrm{kg} \mathrm{m}^{-3}\right)\end{array}$ \\
\hline 0.10 & 0.237 & 0.317 & 0.40 & 5.7 & 1004 \\
\hline 0.20 & 0.223 & 0.297 & 0.37 & 5.6 & 970 \\
\hline 0.40 & 0.218 & 0.300 & 0.37 & 5.2 & 950 \\
\hline 0.70 & 0.211 & 0.289 & 0.38 & 5.1 & 960 \\
\hline 1.00 & 0.213 & 0.292 & 0.38 & 5.3 & 980 \\
\hline $\begin{array}{l}\text { Layer base } \\
\text { depth }(\mathrm{m})\end{array}$ & $\begin{array}{c}\text { Organic } \\
\text { carbon } \\
(\%)\end{array}$ & $\begin{array}{c}\text { Total nitrogen } \\
(\%)\end{array}$ & $\begin{array}{l}\text { P Mehlich } \\
\text { (mg/dm3) }\end{array}$ & $\begin{array}{c}\mathrm{Ca} \\
(\mathrm{cmolc} / \mathrm{dm} 3)\end{array}$ & $\begin{array}{c}\mathrm{Mg} \\
\text { (cmolc/dm3) }\end{array}$ \\
\hline 0.10 & 1.6 & 0.13 & 7.86 & 2.21 & 0.32 \\
\hline 0.20 & 1.6 & 0.13 & 12.86 & 0.87 & 0.07 \\
\hline 0.40 & 1.2 & 0.11 & 1.34 & 0.39 & 0.01 \\
\hline 0.70 & 0.9 & 0.10 & 0.42 & 0.39 & 0.01 \\
\hline 1.00 & 0.7 & 0.09 & 0.22 & 0.30 & 0.00 \\
\hline $\begin{array}{l}\text { Layer base } \\
\text { depth }(\mathrm{m})\end{array}$ & $\mathrm{K}(\mathrm{mg} / \mathrm{dm} 3)$ & $\begin{array}{l}\text { Sum of bases } \\
\text { (cmolc/dm3) }\end{array}$ & $\begin{array}{c}\text { Cation } \\
\text { exchange } \\
\text { capacity } \\
\text { (cmolc/dm3) }\end{array}$ & $\begin{array}{c}\text { Base } \\
\text { saturation (\%) }\end{array}$ & $\begin{array}{c}\text { Aluminium } \\
\text { saturation (\%) }\end{array}$ \\
\hline 0.10 & 50.09 & 2.66 & 6.86 & 38.75 & 0.54 \\
\hline 0.20 & 44.84 & 1.06 & 5.66 & 18.24 & 14.56 \\
\hline 0.40 & 40.82 & 0.51 & 4.88 & 10.39 & 20.63 \\
\hline 0.70 & 31.44 & 0.48 & 3.65 & 12.88 & 22.86 \\
\hline 1.00 & 22.54 & 0.36 & 2.43 & 14.72 & 1.44 \\
\hline
\end{tabular}

\section{Modeling off-season maize production}

The CSM-CERES-Maize model of DSSAT version 4.6 (Hoogenboom et al., 2014), previously parameterized and evaluated for the cultivar DKB390PRO, was used to simulate the yield of maize sown after soybean during three sowing dates recommended by the Climate Risk Zoning (ZRC) of the Brazilian Ministry of Agriculture (MAPA, 2014), including January 2, 9, and 16. The simulations were conducted for a period of 33 years, from 1980 to 2013. The model was set to simulate a typical off-season maize production system. Maize was sown in $0.5 \mathrm{~m}$ row space and 50,000 plants ha ${ }^{-1}$. The simulations begin a month before the sowing date so that the model could perform the soil-water balance and estimate more accurately the initial soil-moisture conditions.

\section{Simulation data}

A series of 33 years of daily minimum and maximum temperature, precipitation and sunlight hours was obtained from the Brazilian National Institute of Meteorology (INMET). The data were checked for consistency, the Weatherman tool (Pickering et al., 1994) of DSSAT was used to fill in missing data for periods smaller than seven days. Missing data for longer periods were completed with data from the nearest weather station with similar elevation. The incident solar radiation was estimated from daily data of sunlight hours using the equation of Angstrom-Prescott (Angstrom, 1924; Prescott, 1940), implemented in Weatherman. 


\section{Simulated Scenarios}

The simulated scenarios consisted on the combination of maize cultivars with different rooting depths, different amounts of residue on the soil surface, and two rates of $\mathrm{N}$ fertilization, generating a combination of 18 scenarios.

The scenario of shallow root depth represents a maize cultivar with a root depth of $0.30 \mathrm{~m}(\mathrm{Rd} 30)$ and was used as a proxy to simulated a cultivar with little tolerance to $\mathrm{Al}^{3+}$ and to low $\mathrm{pH}$; the scenario of average root depth corresponds to a cultivar with a root depth of $0.50 \mathrm{~m}(\mathrm{Rd50})$ typical of maize grown in the region (baseline); the scenario of deep root depth corresponds to a cultivar with a root depth of $0.70 \mathrm{~m}(\mathrm{Rd} 70)$, which corresponds to a cultivar with a rooting system expected on amended soils.

The no residue scenario (Res0) represents a non-suitable tillage system; the $3.5 \mathrm{t} \mathrm{ha}^{-1}$ (Res3.5) of residue on the soil surface represents a typical no-tillage system currently used in Central-West of Brazil (baseline scenario); the scenario of $5 \mathrm{tha}^{-1}$ (Res5) of residue represents an improved no-tillage system.

Each combination of root depth residue scenario was subjected to two scenarios of nitrogen fertilization rates: recommended $\mathrm{N}$ rate $(\mathrm{NL})$ for off-season maize corresponding to $32 \mathrm{~kg} \mathrm{ha}^{-1}$ of $\mathrm{N}$ as mono-ammonium phosphate (MAP) at sowing plus $28 \mathrm{~kg} \mathrm{ha}^{-1}$ of $\mathrm{N}$, as urea sidedressed 25 days after sowing and high $\mathrm{N}$ rate $(\mathrm{NH})$ recommended for high productivity goals and consisting of $40 \mathrm{~kg} \mathrm{ha}^{-1}$ of $\mathrm{N}$ as MAP at sowing plus $300 \mathrm{~kg}$ $\mathrm{ha}^{-1}$ of $\mathrm{N}$ as urea split sidedressed at 25 and 40 days after sowing (Table 2).

\section{Statistical Analysis}

We analyzed the simulated average yield data and the average yield changes of each scenario as compared to the baseline. Results were analyzed as a randomized block in $3 \times 3 \times 2$ factorial (rooting depth $x$ amount of residue $\times \mathrm{N}$ rate). The statistical program SISVAR 5.4 (Ferreira, 2011) was used to determine the effect of each treatment and the interactions as well as to run an analysis of variance. Means were separatred using the Tukey test at alpha $=5 \%$.

\section{Results and discussion}

Maize yield was affected by the amount of residue left on the soil surface, by the depth of the rooting system of the cultivar used and by the rate of nitrogen used (Figure 2).

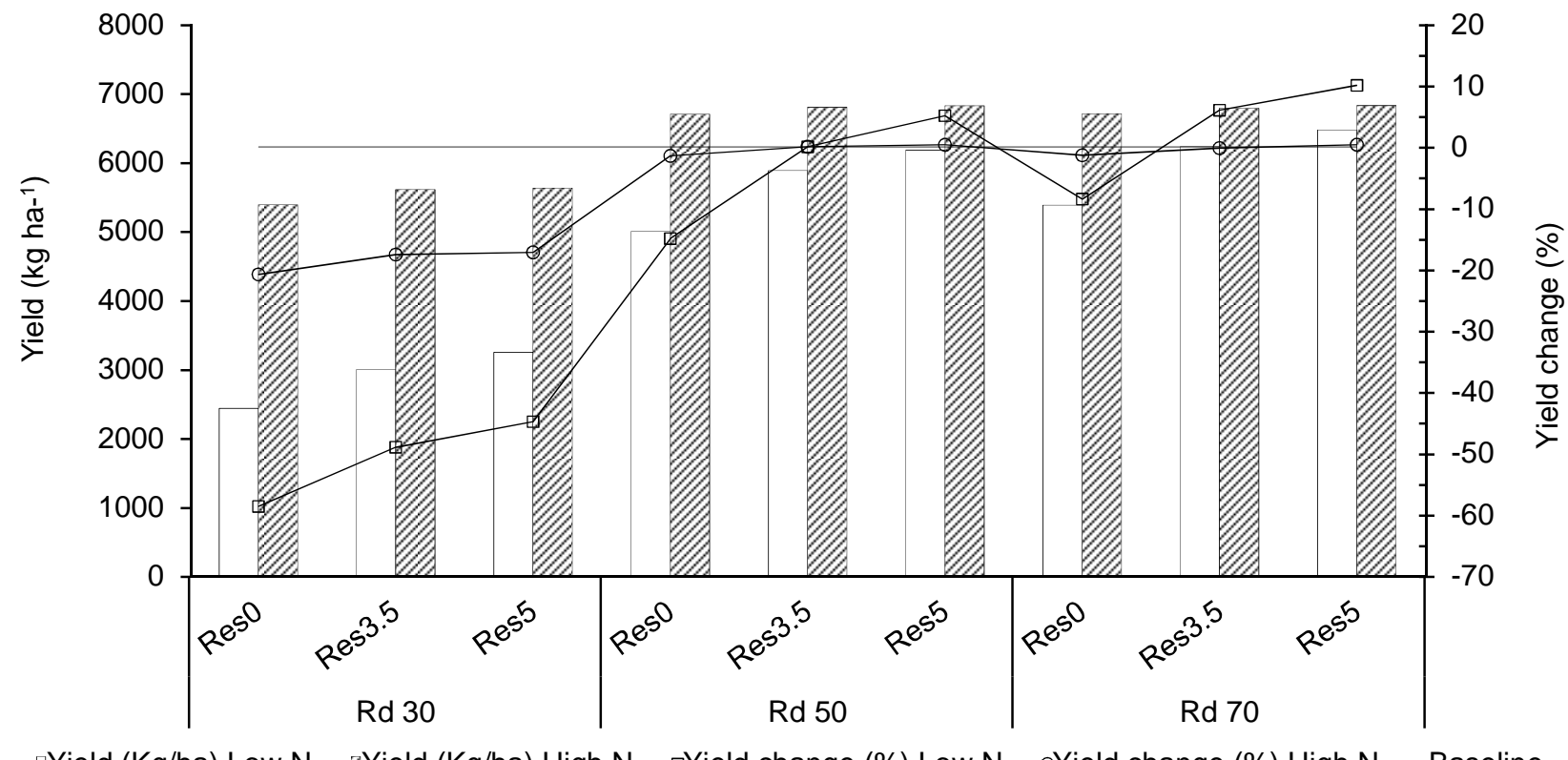

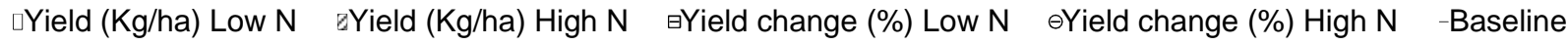

Figure 2. Yield and yield change for different scenarios of amount of residue at the soil surface, rooting system depth, and nitrogen fertilization rate. 
As compared to the baseline (Res3.5Rd50), the use of a cultivar with a shallow root depth $(0.30 \mathrm{~m})$ decreased yield by $45 \% ; 49 \%$ and $59 \%$ for the scenarios of $5.0 ; 3.5$ and $0 \mathrm{t} \mathrm{ha}^{-1}$ of residue, respectively (Figure 3). For scenarios of no residue, the use of cultivars with mid $(0.5 \mathrm{~m})$ to deep $(0.7 \mathrm{~m})$ root depths reduced the maize yield by $15.0 \%$ and $8.5 \%$, respectively, as compared to the baseline. In contrast, the association of a cultivar with deeper rooting system and higher amounts of residue on the soil surface has the potential to increase yield by $10.0 \%$ (Figure 3), which was found to be the best scenario to reduce the risks of low off-season yield associate to limited soil water in the region. Our simulated results are in agreement with field research in the region reporting that crops with deep root system have better access to soil water (Alvarenga \& Cruz, 2003). Our results are also in agreement with a modeling study that evaluated the consequences of climate change on maize production for conditions in Sete Lagoas, Minas Gerais; the authors report that keeping crop residue on the soil surface and using cultivars with deeper rooting system have the potential to mitigate the consequences of low precipitation (Souza et al., 2014).

For the high $\mathrm{N}$ rate treatment, as compared to the baseline (Res3.5Rd50), yield of shallow root depth maize with increased residue on the soil surface (from 0 to 3.5 and to $5.0 \mathrm{t} \mathrm{ha}^{-1}$ was reduced by $21 \%, 18 \%$ and $17 \%$, respectively (Figure 3). Our simulation results indicate that high nitrogen rate have little to no response on the amount of residue left on the soil surface when using cultivars with root depths of 0.5 or $0.7 \mathrm{~m}$. Our results indicate that keeping crop residue on the soil surface is more important if using shallow root depth cultivars or in situations where the soil amendment for $\mathrm{Al}$ or low pH is less than desirable. In addition, the residue will preserve the soil moisture minimizing the negative effects of limited water (Peres et al., 2010).

Maize responded to both, residue left on the soil surface and to root depth to each scenario of nitrogen fertilization. The yield reduction due to the use of cultivars with shallow rooting system associated with little residue on the soil surface was significantly higher in the scenario of low nitrogen rate as compared to that of high nitrogen rate.

Our results indicate a large inter-annual yield variability, represented by the high amplitude between the maximum and minimum simulated yield (Figure 3 ). Although the yield variability was lower for scenarios of shallow root depth, the median yield was considerably lower as compared to scenarios of $0.5 \mathrm{~m}$ and $0.7 \mathrm{~m}$ root depth. The use of high nitrogen fertilizer rates favored the increment of yield in all root depth and of residue scenarios. However, the crop response to nitrogen fertilization was higher in scenarios of cultivars with shallow rooting system and small amount of residue on the soil surface as compared to the other scenarios. In years with favorable soil water conditions, all cultivar responded to the application of higher nitrogen rate, increasing variability of yield.

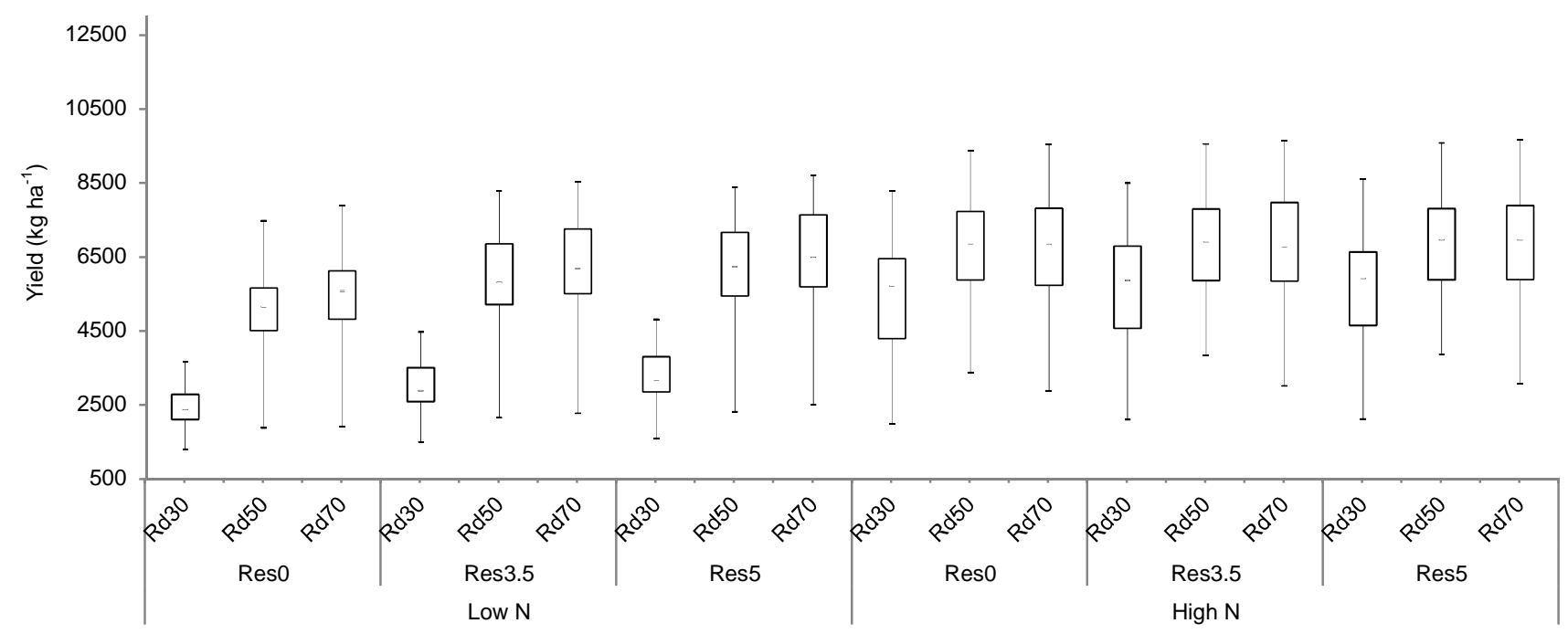

Treatments

Figure 3. Variability of maize grain yield for different scenarios of root depth, crop residue left on the soil surface, and nitrogen rate.

In years with favorable weather conditions, maize tended to respond better to nitrogen fertilization and to have a higher water use efficiency. Similar results were obtained by Bonfim-Silva et al. (2007), who evaluated the response of grass pasture to $\mathrm{S}$ and $\mathrm{N}$ fertilization in degraded soil and concluded that the fertilization contributed positively to the recovery of the grass crop increasing the leaf area and dry matter, and improving the efficiency of water use. Maize usually responds to nitrogen fertilization; rather than strategies like split 
applications, evidences in the region show that better distribution of rainfall is more important for better yield (Ragagnin et al., 2010).

The interaction between the rooting system depth and the amount of residue left on the soil surface were not significant at a $5 \%$ level (Table 2). Yield of cultivars with different root depth was not affected by the amount of residue left on the soil surface. The root depth $\mathrm{x}$ residue and root depth $\mathrm{x} N$ rate interactions were significant $($ alpha $=0.05)$ while the root depth $\times$ residue $\times \mathrm{N}$ rate was not significant.

Table 2 - Significance of $F$ values for sources of variation of off-season maize yield.

\begin{tabular}{cc}
\hline Variation Factor & Pr $>$ F \\
Root depth & $0.0000^{\star}$ \\
Residue & $0.0000^{\star}$ \\
N level & $0.0000^{\star}$ \\
Rd $\times$ Res & $0.9319^{\mathrm{ns}}$ \\
Rd $\times$ N & $0.0000^{\star}$ \\
Res $\times$ N & $0.0000^{\star}$ \\
Rd $\times$ Res $\times N$ & $0.3755^{\mathrm{ns}}$ \\
CV $(\%)$ & 10.37 \\
\hline
\end{tabular}

Values $\mathrm{Pr}>\mathrm{Fc}$ equal to or less than 0.05 indicates a significant difference at $5 \%$ probability.

Table 3 - Yield of off season maize as affected by root depth and $\mathrm{N}$ rates.

\begin{tabular}{|c|c|c|}
\hline \multirow{2}{*}{ Root depth (m) } & \multicolumn{2}{|c|}{ N Level } \\
\hline & Low & High \\
\hline 0.3 & 2889 aA & $5537 \mathrm{aB}$ \\
\hline 0.5 & $5683 \mathrm{bA}$ & $6770 \mathrm{bB}$ \\
\hline 0.7 & $6024 \mathrm{cA}$ & $6769 \mathrm{bB}$ \\
\hline
\end{tabular}

Within a colum (lower case) and within line (upper case), means with the same letter are not significanly different at $5 \%$ probability.

The analysis of variance of treatments was decomposed to assess the root depth $\mathrm{N}$ rate and residue $\times \mathrm{N}$ rate interaction on yield (Tables 3 and 4). Significant differences on yield were found due to the interaction recommended $\mathrm{N}$ rate (low $\mathrm{N}$ ) $x$ root depth (Table 3). A cultivar with root depth of $0.7 \mathrm{~m}$ has the potential to yield $6024 \mathrm{~kg} \mathrm{ha}^{-1}$. Our results indicate that stimulating root growth by using cultivars tolerant to $\mathrm{Al}^{+++}$or properly amending the soil is crucial to improve yield. On the other hand, significant differences on yield were observed with high $\mathrm{N}$ rate only for root depth from $0.3 \mathrm{~m}$ to $0.5 \mathrm{~m}$. These results indicate the importance of proper soil amendment for suitable off-season maize yield since a high $\mathrm{N}$ rate could not compensate for an inadequate soil amendment. Regardless of the root depth, maize significantly responded to high $\mathrm{N}$ rates, suggesting that some adjustment on the fertilization levels for the off-season maize might be required.

Significant differences on yield were found due to the residue $\times \mathrm{N}$ rate interaction (Table 4). For the recommended $\mathrm{N}$ rate (low $\mathrm{N}$ ), the effect of residue on yield was significant while no differences were found for the high $\mathrm{N}$ rate. Regardless of the amount of crop residue left on the soil surface, the off-season maize crop positively responded the increment of $\mathrm{N}$. Our results indicate that the best tillage practice for a condition low $\mathrm{N}$ 
rate corresponds to that leaving $5 \mathrm{t} \mathrm{ha}^{-1}$ of residue in the soil surface.

Tabela 4 - Yield of off season maize as affected by crop residue and $\mathrm{N}$ rates.

\begin{tabular}{ccc}
\hline & \multicolumn{2}{c}{ N Level } \\
\cline { 3 - 4 } Residue $\left(\mathbf{t ~ h a}^{-1}\right)$ & Low & High \\
\hline $\mathbf{0}$ & $4268 \mathrm{aA}$ & $6261 \mathrm{aB}$ \\
\hline $\mathbf{3 . 5}$ & $5034 \mathrm{bA}$ & $6394 \mathrm{aB}$ \\
& $5294 \mathrm{cA}$ & $6421 \mathrm{aB}$ \\
\hline
\end{tabular}

Within a colum (lower case) and within line (upper case), means with the same letter are not significanly different at $5 \%$ probability.

\section{Conclusions}

Our simulation approach indicate that off-season maize yield was affected by $\mathrm{N}$ rate, the amount of residue left by the previous soybean crop, and by the root depth of the cultivar used. Regardless of the amount of residue on the soil surface and on the root depth of the cultivar, maize responded to high $\mathrm{N}$ rate.

For both low and high $\mathrm{N}$ rate scenarios, the off-season maize performed better with root depth of $0.5 \mathrm{~m}$ or 0.7 $\mathrm{m}$ than cultivars with shallow root system, indicating that proper amendment of soils for $\mathrm{Al+++}$ and $\mathrm{pH}$ or the use of cultivar tolerant to aluminum are both important strategies to improve yield.

The recommended $\mathrm{N}$ rate used in off-season production positively responded to residue management but did not respond to high $\mathrm{N}$ rates.

The yield reduction due to the interaction of cultivars with shallow root depth $\mathrm{x}$ little to no residue on the soil surface was considerably higher in the scenario of low $\mathrm{N}$ rate as compared to that of high $\mathrm{N}$ rate.

Under a low $\mathrm{N}$ rate scenario, the combination of a cultivar with $0.5 \mathrm{~m}$ root depth with $5 \mathrm{t} \mathrm{ha}^{-1}$ of residue on the soil surface indicated to have potential to increase yield by $5.1 \%$, while the use of a cultivar with a deep rooting system $(0.7 \mathrm{~m})$ with the same amount of residue may boost the yield by $10 \%$.

When cultivars with root depths of $0.5 \mathrm{~m}$ or $0.7 \mathrm{~m}$ were used, the higher fertilization did not lead to higher yields.

The root depth $\mathrm{x}$ residue interaction was not significant; however, both showed significant interaction with $\mathrm{N}$ rates. 


\section{References}

Albuquerque, P. E., \& Resende, M. 2002. Cultivo do milho: Manejo da irrigação. Comunicado Técnico 47. Sete Lagoas, MG, Brasil: Ministério da Agricultura Pecuária e Abastecimento.

Alvarenga, R. C., \& Cruz, J. C. 2003. Manejo de solos e agricultura irrigada. In: M. Resende, P. E. Albuquerque, \& L. Couto, $A$ cultura do milho irrigado (p. 317). Brasília: Embrapa Informação Tecnológica.

Amaral, T. A., Andrade, C. d., Lima, A. C., Souza, I. R., Souza, A. A., Teixeira, T. C., \& Paixão, J. S. 2014. Análise da Sensibilidade da Cultura do Milho às Mudanças Climáticas Empregando Modelos de Simulação: 3 - Respostas ás alterações na taxa de radiação solar. XXX CONGRESSO NACIONAL DE MILHO E SORGO. Salvador, BA, Brasil: XXX CONGRESSO NACIONAL DE MILHO E SORGO.

Amaral, T. A., Andrade, C. d., Souza, I. R., Lima, A. C., Souza, A. A., \& Teixeira, T. C. 2014. Simulação dos impactos da concentração de dióxido de carbono, morfologia radicular e palhada na produtividade do milho. XXX CONGRESSO NACIONAL DE MILHO E SORGO. Salvador, BA, Brasil: XXX CONGRESSO NACIONAL DE MILHO E SORGO.

Angstrom, A. 1924. Solar and terrestrial radiation. Quarterly Journal of the Royal Meteorological Society, p. 210.

Babel, M. S., \& Turyatunga, E. 2015. Evaluation of climate change impacts and adaptation measures for maize cultivation in the western Unganda agro-ecological zone. 239-254.

Bonfim-Silva, E. M., Monteiro, F. A., \& Silva, T. J. A. D. 2007. Nitrogênio e enxofre na produção e no uso de água pelo capimbraquiária em degradação. Revista Brasileira de Ciência do Solo, 31(2), 309-317.

Brasil, M. D. 2014. Portaria no 17 de 20 de novembro de 2014. Fonte: Secretaria de Política Agrícola: http://www.agrolink.com.br/downloads/ZONEAMENTO\%20MILHO\%20GOI\%C3\%81S\%202\%C2\%BA(1).pdf

Cardoso, M. R. D., Marcuzzo, F. F. N., \& Barros, J. R. 2015. Classificação Climática de Köppen-Geiger para o Estado de Goiás e o Distrito Federal.ACTA GEOGRÁFICA, 8(16), 40-55.

Dourado Neto, D., Sparovek, G., Figueredo Junior, L. D., Fancelli, A. L., Manfron, P. A., \& Medeiros, S. L. 2004. Modelo para estimação da produtividade de grãos de milho deplecionada com base no balanço hídrico no solo. Revista Brasileira de Agrometeorologia, 359-367.

Ferreira, D. F. 2011. Sisvar: a computer statistical analysis system. Ciência e agrotecnologia, 35(6), 1039-1042.

Floss, E. L. 2002. Aveia, um sustentáculo do sistema de semeadura direta. Revista Plantio Direto, n72.

Foloni, J. S., Calonego, J. C., Catuchi, T. A., Belleggia, N. A., Tiritan, C. S., \& Barbosa, A. D. 2015. Cultivares de milho em diferentes populações de plantas com espaçamento reduzido na safrinha. Revista Brasileira de Milho e Sorgo, 312325.

Hoogenboom, G., Jones, J. W., Wilkens, P. W., Porter, C. H., Boote, K. J., Hunt, L. A., Tsuji, G. Y. 2014. Decision Support System for Agrotechnology Transfer: version 4.6. DSSAT Foundation. Prosser Washington.

IBGE. 2015. Instituto Brasileiro de Geografia e Estatística. Fonte: SIDRA: http://www.sidra.ibge.gov.br/bda/tabela/listabl.asp?c=839\&z=p\&o=29

Jones, C.A., Kiniry, J.R., 1986. CERES-Maize: A Simulation Model for Maize Growth and Development. A\&M University Press, College Station, TX, USA.

Jones, J. W.; Hoogenboom, G.; Porter, C. H.; Boote, K. J.; Batchelor, W. D.; Hunt, L. A.; Wilkens E , U.; Singh E , A. J; Gijsman A.; Ritchie, J. T. 2003. The DSSAT cropping system model. European journal of agronomy, 18(3), $235-265$.

Kassie, B., Asseng, S., Rotter, R., Hengsdijk, H., Ruane, A., \& Van Ittersum, M. 2015. Exploring climate change impacts and 
adaptation options for maize production in the Central Rift Valley of Ethiopia using different climate change scenarios and crop models. Climatic Change, 145-158.

Köppen, W. 1936.Das geographisca System der climate. Gebr, Borntraeger, 1-44.

Leite, L. F., Oliveira, E. P., Santos, A., \& Gessí , C. 2013. Desempenho de milho safrinha em duas épocas de semeadura e populações de plantas, em Dourados, MS. XII Seminário Nacional Milho Safrinha. Dourados, MS, Brasil: XII Seminário Nacional Milho Safrinha.

Moreira, J. A., Stone, L., Pereira Filho, I. A., \& Cruz, J. 2011. Eficiência de uso de água pela cultura do milho (Zea mays) em função da cobertura do solo pela palhada no sistema plantio direto. Resumos do VII Congresso Brasileiro de Agroecologia. Fortaleza, CE, Brasil: Resumos do VII Congresso Brasileiro de Agroecologia.

Paixão, J. S., Andrade, S. L., Garcia y Garcia, A, Amaral, T. A., S., N. A., \& Marin, F. R. 2014. An alternative approach to the actual brazilian maize crop zoning. Revista Brasileira de Milho e Sorgo, 347-363.

Peres, J., Souza, C., \& Lavorenti, N. 2010. Avaliação dos efeitos da cobertura de palha de cana-de-açúcar na umidade e na perda de água do solo. Engenharia Agrícola, 875-886.

Pickering, N. B., W., H. J., Jones, H., \& Godwin, D. 1994. Weatherman: a utility for managing and generating daily weather data. Agronomy Journal, 332-337.

Prescott, J. A. 1940. Evaporation from a water surface in relation to solar radiation. Transactions Royal Society of South Australia, 114-118.

Ragagnin, V. A., Junior, D. G., Klein, V., Lima, R. S., Costa, M. M., \& Neto, O. V. 2010. ADubação nitrogenada em milho safrinha sob plantio direto em milho safrinha sob plantio direto em Jataí - GO. Global Sciense Technology 70-77.

Rhoads, F.M.; Bennett. Corn. 1990. In: Stewart, B.A. \& Nielsen, D.R., co-ed, Irrigation of Agricultural Crops. American Society of Agronomy, Madison. 569-596.

Ribeiro, A. C., Guimarães, P. T., \& Alvarez V, V. H. 1999. Recomendação para o uso de corretivos e fertilizantes em Minas Gerais. Viçosa: Viçosa: Comissão de Fertilidade do Solo do Estado de Minas Gerais.

Silva, P. P., Andrade, C. L., Amaral, T. A., Castro, A. P., Teixeira, T. C., \& Paixão, J. S. 2014. Análise da Sensibilidade da Cultura do Milho às Mudanças Climáticas Empregando Modelos de Simulação: 1 - Resposta às Alterações na Temperatura do Ar. XXX CONGRESSO NACIONAL DE MILHO E SORGO . Salvador, BA, Brasil: XXX CONGRESSO NACIONAL DE MILHO E SORGO .

Souza, A. A., Andrade, C. L., Amaral, T. A., Silva, P. P., Teixeira, T. C., \& Paixão, J. S. 2014. Análise da Sensibilidade da Cultura do Milho às Mudanças Climáticas Empregando Modelos de Simulação: 2 - Resposta às Alterações na Precipitação. XXX CONGRESSO NACIONAL DE MILHO E SORGO. Salvador, BA, Brasil: XXX CONGRESSO NACIONAL DE MILHO E SORGO.

Zandoná, R. R., Beutler, A. N., Burg, G. M., Barreto, C. F., \& Schmidt, M. R. 2015. Gesso e calcário aumentam a produtividade e. Pesq. Agropec. Trop., 128-137. 